\title{
ANALISIS TATA LETAK GUDANG DENGAN MENGGUNAKAN METODE DEDICATE STORAGE
}

\author{
Analysis of Warehouse Layout using Dedicate Storage Method \\ Olivia Audrey ${ }^{1}$, Wayan Sukania ${ }^{1}$, Siti Rohana Nasution ${ }^{2 *}$ \\ ${ }^{1}$ Program Studi Teknik Industri, Universitas Tarumanagara, Jl. Tanjung Gedong Baru Blok A No.1 Tomang \\ Jakarta Barat 11440, Indonesia \\ ${ }^{2}$ Program Studi Teknik Industri, Universitas Pancasila, Srengseng Sawah Jagakarsa, Jakarta 12640, Indonesia
}

Informasi artikel

Diterima: 26/02/2019

Direvisi : 01/03/2019

Disetujui: 04/03/2019

\begin{abstract}
Abstrak
Pengelolaan gudang yang baik akan mempengaruhi didalam memperlancar proses produksi. Dengan meningkatnya Kapasitas produksi mencapai 93.624 kaleng atau setara dengan 3.901 kardus dan terdiri dari 20 jenis produk. Hal ini yang menyebabkan perlunya dilakukan pengaturan tata letak gudang guna mengatur posisi penyimpanan dan penyusunan barang jadi. Barang jadi hasil produksi akan ditempatkan dan disusun secara acak bergantung pada posisi gudang yang kosong. Hal ini mengakibatkan waktu angkut menjadi lebih lama karena adanya proses pencarian. Oleh karena itu diperlukan adanya perbaikan tata letak gudang barang jadi dengan metode dedicated storage. Metode dedicated storage merupakan metode penyusunan tata letak dimana penyimpanan produk disusun berdasarkan banyaknya aktivitas keluar masuk dengan jarak tempuh terpendek terhadap I/O point (throughput). Dengan penggunaan metode ini, maka barang jadi yang akan disimpan akan menempati lokasi yang tetap sehingga memudahkan operator dalam menyimpan dan mengambil produk sehingga aliran produk menjadi lancar. Dari hasil perancangan tata letak didapatkan 3 alternatif dengan jenis aliran barang yang berbeda. Tata letak dengan arus lurus, arus " $U$ " dan arus " $L$ " memiliki total jarak tempuh $177.714 \mathrm{~m}, 178.147,71 \mathrm{~m}$, dan $178.455,8 \mathrm{~m}$. Alternatif tata letak yang dipilih adalah arus lurus karena memiliki jarak tempuh terpendek dan jenis tata letak ini memiliki proses penyimpanan dan pengambilan barang relatif lebih cepat.
\end{abstract}

Kata Kunci: tata letak gudang, dedicated storage, throughput, jarak tempuh.

\begin{abstract}
Warehouse management will influence in expediting the production process. With increasing, production capacity reached 93,624 cans or the equivalent of 3,901 boxes and consists of 20 types of products. This is what causes the need for a warehouse layout to adjust the position of storage and preparation of finished goods Finished goods will be placed and compiled randomly depends on the available space of the warehouse. Thus, the transport process becomes long since there is a lookup process. Therefore, the warehouse layout of finished goods needs to be improved with dedicated storage method. Dedicated storage method is a layout method where product storage is arranged based on in and out activity with the shortest travel distance towards $/ / O$ point (throughput). With this method, the finished goods will be located in a fixed location so this will ease the operator in storing and pulling the product to make the product flow run swiftly. This layout design is resulting in 3 alternatives with a different kind of product flow. Layout with straight flow, " $U$ " flow and " $L$ " flow have the travel distance of $177.714 \mathrm{~m}, 178,147,71 \mathrm{~m}$ and $178,455,8 \mathrm{~m}$ consecutively. The layout alternative that has been chosen is the vertical flow since it has the shortest mileage and this kind of layout relatively has the fastest product's storing and retrieving process.
\end{abstract}

Keywords: warehouse layout, dedicated storage, throughput, travel distance.

*Penulis Korespondensi: +62 8161400836

email: siti_rohana@univpancasila.ac.id 


\section{PENDAHULUAN}

Hasil produksi dari perusahaan biasanya sebelum dikirimkan ke konsumen di lakukan penyimpanan sementara, bagi perusahaan yang menggunakan sistem make to stock ini maka penyimpan barang di gudangsangat penting karena sangat mempengaruhi dalam pelayan kepuasan pelanggan.

Untuk itu perlu dilakukan penataan lokasi penyimpanan produk pada gudang produk jadi dengan menggunakan metode dedicated storage. Metode dedicated storage menyusun produk dengan menempatkan satu produk pada satu lokasi penyimpanan saja. Penempatan ini didasarkan pada perbandingan aktivitas tiap produk dengan kebutuhan ruang yang dibutuhkan produk tersebut kemudian didapatkan urutan produk dari yang terbesar sampai terkecil.

Adapun tujuan dari metode ini adalah untuk memberikan perbaikan tata letak gudang produk jadi yang memudahkan penyimpanan, penyusunan, serta pengambilan barang jadi di gudang.

\section{Gudang}

Gudang adalah tempat yang dibebani tugas untuk menyimpan barang yang akan dipergunakan dalam produksi, sampai barang tersebut diminta sesuai jadwal produksi. Gudang dapat digambarkan sebagai suatu sistem logistik dari sebuah perusahaan yang berfungsi untuk menyimpan produk dan perlengkapan produksi lainnya dan menyediakan informasi mengenai status serta kondisi material atau produk yang disimpan di gudang sehingga informasi tersebut mudah diakses oleh siapapun yang berkepentingan (Apple, 1990; Francis \& White, 1992).

\section{Dedicated Storage}

Dedicated Storage adalah metode yangsering disebut sebagai penyimpanan yang sudah tertentu dan tetap karena lokasi untuk tiap barang sudah ditentukan tempatnya. Jumlah lokasi penyimpanan untuk suatu produk harus dapat mencukupi kebutuhan ruang penyimpanan yang paling maksimal dari produk tersebut. Ruang penyimpanan yang diperlukan adalah kumulatif dari kebutuhan penyimpanan maksimal dari tiap jenis produknya jika produk yang akan disimpan lebih dari satu jenis (Tompkins, et al. 2010; Francis \& White, 1992).

\section{Tata Letak Lurus Sederhana}

Tata Letak Lurus Sederhana merupakan tata letak dimana arus barang akan berbentuk garis lurus. Proses keluar masuk barang tidak melalui lorong atau gang yang berkelok-kelok sehingga proses penyimpanan dan pengambilan barang relatif lebih cepat. Lokasi barang yang disimpan dibedakan antara barang yang bersifat fastmoving dan slowmoving (Tompkins, et al. 2010; Purnomo, 2004).

Tata Letak Arus "U"

Tata Letak Arus "U" merupakan tata letak dimana arus barang berbentuk " $\mathrm{U}$ ". Proses keluar masuk barang melalui lorong atau gang yang berkelok-kelok sehingga proses penyimpanan dan pengambilan barang relatif lebih lama. Lokasi barang yang akan disimpan dibedakan antara barang yang bersifat fastmoving dan slowmoving (Tompkins, et al. 2010; Purnomo, 2004).

\section{Tata Letak Arus "L"}

Tata Letak Arus "L" merupakan tata letak dimana arus barang berbentuk " $\mathrm{L}$ " dan proses keluar masuk barang melalui lorong atau gang yang tidak terlalu berkelokkelok sehingga proses penyimpanan dan pengambilan barang relatif cepat. Lokasi barang yang akan disimpan dibedakan antara barang yang bersifat fastmoving dan slowmoving (Tompkins, et al. 2010; Purnomo, 2004).

\section{Throughput}

Throughput adalah pengukuran aktivias atau penyimpanan yang sifatnya dinamis, yang menunjukkan aliran dalam penyimpanan. Istilah throuhput digunakan sebagai ukuran jumlah aktivitas storage dan retrieval yang terjadi per periode waktu (Sule, 2009).

\section{METODOLOGI PENELITIAN}

Penelitian ini terdiri dari beberapa tahapan yang dimulai dari tahap studi pustaka yangberkaitan dengan topik penelitian sampai mendapat kesimpulan penelitian. Berikut merupakan tahapan yang akan dilakukan di penelitian yaitu:

1. Menentukan topik penelitian

2. Melakukan studi literatur

3. Mempelajari tata letak PT BIJ

4. Pengambilan data 
Pada tahapan ini dilakukan pengumpulan data atau informasi yang dibutuhkan dalam poses penelitian yang akan digunakan dalam proses perhitungan dan proses analisis untuk menghasilkan usulan perbaikan bagi perusahaan. Data-data yang diambil untuk penelitian ini yaitu:
a. Profil perusahaan
b. Data barang Jadi yang masuk dan keluar
c. Luas gudang

5. Melakukan pengolahan data
a. Evaluasi kondisi awal gudang barang jadi
b. Perhitungan kebutuhan luas lantai dengan metode dedicated storage
c. Perhitungan kebutuhan luas lantai dengan metode dedicated storage
d. Penentuan prioritas pengalokasian produk jadi

6. Usulan perbaikan

Setelah dilakukan perhitungan dan penentuan prioritas maka dilakukan pembuatan tata letak yang baru sebagai usulan perbaikan untuk mengatasi permasalahan tersebut yaitu:

a. Pembuatan alternatif tata letak gudang barang jadi

b. Penentuan tata letak yang terbaik

7. Kesimpulan dan saran Menarik kesimpulan hasil penelitian yang dilakukan dan memberikan saran untuk penelitian selanjutnya.

\section{HASIL DAN PEMBAHASAN}

\section{Perhitungan Throughput}

Berdasarkan hasil hasil perhitungan barang jadi yang masuk dan keluar dari gudang barang jadi PT BIJ menunjukkan bahwa jumlah throughput adalah sebanyak 6.582 kali. Artinya total aktivitas perjalanan pemindahan untuk penyimpanan dan pengambilan yang terjadi dalam periode waktu satu tahun adalah sebanyak 6.582 kali. Throughput ( $\mathrm{Tj}$ ) produk barang jadi dari PT BIJ dapat dilihat pada tabel 1 (Warman, 2012).

Penyusunan rankthroughput dilakukan untuk mengetahui jenis produk yang memiliki aktivitas pergerakan yang paling cepat hingga yang paling lambat. Yang mana nantinya dalam perancangan tata letak penyimpanan produk jadi salah satunya beracuan dari hasil rankthroughput tersebut. Ranking Throughput produk barang jadi dari PT BIJdapat dilihat pada Tabel 2.

Tabel 1 Throughput Produk Barang Jadi dari PT BIJ

\begin{tabular}{ccccc}
\hline No & $\begin{array}{c}\text { Kode } \\
\text { Produk }\end{array}$ & $\begin{array}{c}\text { Produk } \\
\text { yang } \\
\text { Diterima }\end{array}$ & $\begin{array}{c}\text { Produk } \\
\text { Yang } \\
\text { Keluar }\end{array}$ & $\begin{array}{c}\text { Throughput } \\
(\mathrm{Tj})\end{array}$ \\
\hline 1 & R101 & 4.584 & 4.343 & 279 \\
2 & R102 & 4.464 & 4.205 & 362 \\
3 & L101 & 4.200 & 3.941 & 255 \\
4 & L102 & 3.624 & 3.374 & 292 \\
5 & L111 & 4.512 & 4.266 & 275 \\
6 & L112 & 3.432 & 3.178 & 276 \\
7 & N101 & 5.448 & 5.196 & 333 \\
8 & N102 & 5.088 & 4.830 & 414 \\
9 & K101 & 6.864 & 6.617 & 422 \\
10 & K102 & 5.760 & 5.515 & 470 \\
11 & R201 & 4.320 & 4.064 & 262 \\
12 & R202 & 4.608 & 4.348 & 374 \\
13 & L201 & 4.656 & 4.394 & 283 \\
14 & L202 & 3.432 & 3.185 & 276 \\
15 & L211 & 4.128 & 3.865 & 250 \\
16 & L212 & 3.336 & 3.096 & 268 \\
17 & N201 & 5.208 & 4.965 & 318 \\
18 & N202 & 4.536 & 4.284 & 368 \\
19 & K201 & 6.216 & 5.965 & 381 \\
20 & K202 & 5.208 & 4.966 & 424 \\
\hline & Total & 93.624 & 88.597 & 6.582 \\
\hline & & & &
\end{tabular}

Tabel 2 Ranking Throughput produk barang jadi PT BIJ

\begin{tabular}{ccc}
\hline No & Kode Produk & Throughput $(\mathrm{Tj})$ \\
\hline 1 & K102 & 470 \\
2 & K202 & 424 \\
3 & K101 & 422 \\
4 & N102 & 414 \\
5 & K201 & 381 \\
6 & R202 & 374 \\
7 & N202 & 368 \\
8 & R102 & 362 \\
9 & N101 & 333 \\
10 & N201 & 318 \\
11 & L102 & 292 \\
12 & L201 & 283 \\
13 & R101 & 279 \\
14 & L112 & 276 \\
15 & L202 & 276 \\
16 & L111 & 275 \\
17 & L212 & 268 \\
18 & R201 & 262 \\
19 & L101 & 255 \\
20 & L211 & 250 \\
\hline
\end{tabular}


Perhitungan Space Requirement

Gudang barang jadi memiliki luas sebesar $204 \mathrm{~m}^{2}$ dengan panjang $12 \mathrm{~m}$ dan lebar $17 \mathrm{~m}$ akan dibagi menjadi 204 slot.

Perhitungan space requirement dalam slot untuk setiap barang dilakukan dengan pembulatan ke atas untuk memastikan tidak ada barang jadi yang kekurangan area penyimpanan. Tabel 3 menunjukkan space requirement untuk setiap barang jadi (Hidayat, 2012; Reinny, 2010).

Tabel 3 Kebutuhan Space Requirement

\begin{tabular}{cccc}
\hline No & $\begin{array}{c}\text { Kode } \\
\text { Produk }\end{array}$ & $\begin{array}{c}\text { Space } \\
\text { Requirement } \\
\text { Teoritis }\end{array}$ & $\begin{array}{c}\text { Space } \\
\text { Requirement } \\
\text { (Sj) }\end{array}$ \\
\hline 1 & R101 & 2,42 & 3 \\
2 & R102 & 4,84 & 5 \\
3 & L101 & 2,42 & 3 \\
4 & L102 & 3,63 & 4 \\
5 & L111 & 2,42 & 3 \\
6 & L112 & 3,63 & 4 \\
7 & N101 & 3,63 & 4 \\
8 & N102 & 6,05 & 7 \\
9 & K101 & 3,63 & 4 \\
10 & K102 & 6,05 & 7 \\
11 & R201 & 2,42 & 3 \\
12 & R202 & 4,84 & 5 \\
13 & L201 & 3,63 & 4 \\
14 & L202 & 3,63 & 4 \\
15 & L211 & 2,42 & 3 \\
16 & L212 & 3,63 & 4 \\
17 & N201 & 3,63 & 4 \\
18 & N202 & 4,84 & 5 \\
19 & K201 & 3,63 & 4 \\
20 & K202 & 6,05 & 7 \\
\hline
\end{tabular}

Berdasarkan perhitungan pada Tabel 3 dihasilkan grafik persentase penggunaan space requirement dari setiap barang jadi yang dapat dilihat pada Gambar 1.

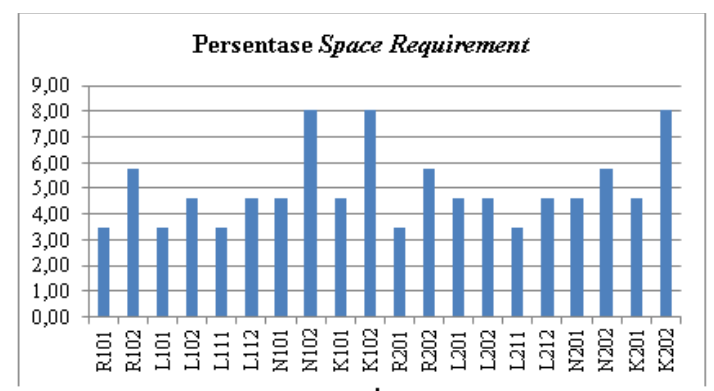

Gambar 1 Persentase space requirement

$$
\begin{aligned}
& \text { Perhitungan Rasio Throughput dengan } \\
& \text { Space Requirement }
\end{aligned}
$$

Setelah mendapatkan hasil perhitungan dari frekuensi penerimaan dan pengeluaran (throughput) dan kebutuhan slot, maka akan dilakukan perhitungan untuk rasio $\mathrm{Tj}$ dan $\mathrm{Sj}$.

Produk dengan nilai rasio $\mathrm{T} / \mathrm{S}$ terbesar akan ditempatkan di slot dengan jarak terkecil, produk dengan nilai rasio T/S kedua terbesar akan ditempatkan di slot dengan jarak kedua terkecil dan seterusnya. Secara teknis cara penempatan seperti ini bertujuan untuk meminimasi jarak tempuh operator dari titik I/O ke slot. Tabel rasio frekuensi penerimaan dan pengeluaran ( $\mathrm{Tj}$ ) dan kebutuhan slot $(\mathrm{Sj})$ dapat dilihat pada Tabel 4.

Tabel 4 Rasio $\mathrm{Tj}$ dan $\mathrm{Sj}$

\begin{tabular}{ccccc}
\hline No & $\begin{array}{c}\text { Kode } \\
\text { Produk }\end{array}$ & $\mathrm{Tj}$ & $\mathrm{Sj}$ & $\mathrm{Tj} / \mathrm{Sj}$ \\
\hline 1 & R101 & 279 & 3 & 93,00 \\
2 & R102 & 362 & 5 & 72,40 \\
3 & L101 & 255 & 3 & 85,00 \\
4 & L102 & 292 & 4 & 73,00 \\
5 & L111 & 275 & 3 & 91,67 \\
6 & L112 & 276 & 4 & 69,00 \\
7 & N101 & 333 & 4 & 83,25 \\
8 & N102 & 414 & 7 & 59,14 \\
9 & K101 & 422 & 4 & 105,50 \\
10 & K102 & 470 & 7 & 67,14 \\
11 & R201 & 262 & 3 & 87,33 \\
12 & R202 & 374 & 5 & 74,80 \\
13 & L201 & 283 & 4 & 70,75 \\
14 & L202 & 276 & 4 & 69,00 \\
15 & L211 & 250 & 3 & 83,33 \\
16 & L212 & 268 & 4 & 67,00 \\
17 & N201 & 318 & 4 & 79,50 \\
18 & N202 & 368 & 5 & 73,60 \\
19 & K201 & 381 & 4 & 95,25 \\
20 & K202 & 424 & 7 & 60,57 \\
\hline
\end{tabular}

\section{Perancangan Tata Letak Perbaikan}

Dengan mengetahui rasio $\mathrm{Tj}$ dan $\mathrm{Sj}$ dari setiap jenis produk, maka dirancang 3 alternatif tata letak perbaikan dengan alur lurus sederhana, arus "U", dan arus "L".

\section{Perhitungan Jarak Tempuh}

Penempatan produk pada ketiga alternatif tata letak disusun berdasarkan nilai $\mathrm{Tj} / \mathrm{Sj}$ terbesar, dan karena rasio barang masuk dan barang keluar lebih dari 1, maka seluruh jarak dihitung dari titik input. Produk dengan $\mathrm{Tj} / \mathrm{Sj}$ terbesar diletakkan paling dekat dengan titik input dan produk dengan $\mathrm{Tj} / \mathrm{Sj}$ terkecil diletakkan paling jauh dengan titik input. Perhitungan total jarak tempuh untuk alternatif 1, 2, dan 3 dapat dilihat pada Tabel 5, 6, dan 7 (Sukania, et al. 2016). 
Tabel 5 Jarak tempuh tata letak alternatif 1

\begin{tabular}{ccccccc}
\hline No & $\begin{array}{c}\text { Kode } \\
\text { Produk }\end{array}$ & Tj/Sj & $\begin{array}{c}\text { Jarak Slot ke } \\
\text { Input }\end{array}$ & $\begin{array}{c}\text { Jarak Slot ke } \\
\text { Output }\end{array}$ & $\begin{array}{c}\text { Jarak Tempuh } \\
\text { ke Input }\end{array}$ & $\begin{array}{c}\text { Jarak Tempuh } \\
\text { ke Output }\end{array}$ \\
\hline 1 & K101 & 105,50 & 20 & 88 & $2.110,00$ & $9.284,00$ \\
2 & K201 & 95,25 & 26 & 82 & $2.476,50$ & $7.810,50$ \\
3 & R101 & 93,00 & 21 & 60 & $1.953,00$ & $5.580,00$ \\
4 & L111 & 91,67 & 24 & 57 & $2.200,00$ & $5.225,00$ \\
5 & R201 & 87,33 & 26 & 55 & $2.270,67$ & $4.803,33$ \\
6 & L101 & 85 & 27 & 54 & $2.295,00$ & $4.590,00$ \\
7 & L211 & 83,33 & 31 & 50 & $2.583,33$ & $4.166,67$ \\
8 & N101 & 83,25 & 42 & 66 & $3.496,50$ & $5.494,50$ \\
9 & N201 & 79,50 & 44 & 64 & $3.498,00$ & $5.088,00$ \\
10 & R202 & 74,80 & 57 & 78 & $4.263,60$ & $5.834,40$ \\
11 & N202 & 73,60 & 61 & 74 & $4.489,60$ & $5.446,40$ \\
12 & L102 & 73,00 & 52 & 56 & $3.796,00$ & $4.088,00$ \\
13 & R102 & 72,40 & 67 & 68 & $4.850,80$ & $4.923,20$ \\
14 & L201 & 70,75 & 58 & 50 & $4.103,50$ & $3.537,50$ \\
15 & L112 & 69,00 & 58 & 50 & $4.002,00$ & $3.450,00$ \\
16 & L202 & 69,00 & 60 & 48 & $4.140,00$ & $3.312,00$ \\
17 & K102 & 67,14 & 121 & 68 & $8.124,29$ & $4.565,71$ \\
18 & L212 & 67,00 & 67 & 41 & $4.489,00$ & $2.747,00$ \\
19 & K202 & 60,57 & 124 & 65 & $7.510,86$ & $3.937,14$ \\
20 & N102 & 59,14 & 143 & 46 & $8.457,43$ & $2.720,57$ \\
\hline \multicolumn{7}{c}{ Total Jarak Tempuh Layout Arus Lurus } \\
\hline \multicolumn{7}{r}{}
\end{tabular}

Tabel 6 Jarak tempuh tata letak alternatif 2

\begin{tabular}{|c|c|c|c|c|c|c|}
\hline No & $\begin{array}{l}\text { Kode } \\
\text { Produk }\end{array}$ & $\mathrm{Tj} / \mathrm{Sj}$ & $\begin{array}{l}\text { Jarak Slot ke } \\
\text { Input }\end{array}$ & $\begin{array}{l}\text { Jarak Slot } \\
\text { ke Output }\end{array}$ & $\begin{array}{c}\text { Jarak } \\
\text { Tempuh ke } \\
\text { Input }\end{array}$ & $\begin{array}{l}\text { Jarak Tempuh } \\
\text { ke Output }\end{array}$ \\
\hline 1 & K101 & 105,50 & 20 & 88 & $2.110,00$ & $9.284,00$ \\
\hline 2 & K201 & 95,25 & 28 & 80 & $2.667,00$ & $7.620,00$ \\
\hline 3 & R101 & 93,00 & 21 & 60 & $1.953,00$ & $5.580,00$ \\
\hline 4 & L111 & 91,67 & 23 & 58 & $2.108,33$ & $5.316,67$ \\
\hline 5 & R201 & 87,33 & 26 & 55 & $2.270,67$ & $4.803,33$ \\
\hline 6 & L101 & 85 & 28 & 53 & $2.380,00$ & $4.505,00$ \\
\hline 7 & L211 & 83,33 & 30 & 51 & $2.500,00$ & $4.250,00$ \\
\hline 8 & N101 & 83,25 & 42 & 66 & $3.496,50$ & $5.494,50$ \\
\hline 9 & N201 & 79,50 & 44 & 64 & $3.498,00$ & $5.088,00$ \\
\hline 10 & R202 & 74,80 & 61 & 74 & $4.562,80$ & $5.535,20$ \\
\hline 11 & N202 & 73,60 & 62 & 73 & $4.563,20$ & $5.372,80$ \\
\hline 12 & L102 & 73,00 & 56 & 52 & $4.088,00$ & $3.796,00$ \\
\hline 13 & R102 & 72,40 & 71 & 64 & $5.140,40$ & $4.633,60$ \\
\hline 14 & L201 & 70,75 & 58 & 50 & $4.103,50$ & $3.537,50$ \\
\hline 15 & L112 & 69,00 & 64 & 44 & $4.416,00$ & $3.036,00$ \\
\hline 16 & L202 & 69,00 & 68 & 42 & $4.692,00$ & $2.898,00$ \\
\hline 17 & K102 & 67,14 & 123 & 66 & $8.258,57$ & $4.431,43$ \\
\hline 18 & L212 & 67,00 & 69 & 39 & $4.623,00$ & $2.613,00$ \\
\hline 19 & K202 & 60,57 & 138 & 51 & $8.358,86$ & $3.089,14$ \\
\hline 20 & $\mathrm{~N} 102$ & 59,14 & 148 & 46 & $8.753,14$ & $2.720,57$ \\
\hline \multicolumn{5}{|c|}{ Total Jarak Tempuh Layout Arus “U” } & $84.542,98$ & $93.604,75$ \\
\hline
\end{tabular}


Tabel 7 Jarak tempuh tata letak alternatif 3

\begin{tabular}{ccccccc}
\hline No & $\begin{array}{c}\text { Kode } \\
\text { Produk }\end{array}$ & Tj/Sj & $\begin{array}{c}\text { Jarak Slot ke } \\
\text { Input }\end{array}$ & $\begin{array}{c}\text { Jarak Slot } \\
\text { ke Output }\end{array}$ & $\begin{array}{c}\text { Jarak Tempuh } \\
\text { ke Input }\end{array}$ & $\begin{array}{c}\text { Jarak Tempuh } \\
\text { ke Output }\end{array}$ \\
\hline 1 & K101 & 105,50 & 20 & 88 & 2110,00 & 9284,00 \\
2 & K201 & 95,25 & 28 & 80 & 2667,00 & 7620,00 \\
3 & R101 & 93,00 & 21 & 60 & 1953,00 & 5580,00 \\
4 & L111 & 91,67 & 23 & 58 & 2108,33 & 5316,67 \\
5 & R201 & 87,33 & 28 & 53 & 2445,33 & 4628,67 \\
6 & L101 & 85 & 28 & 53 & 2380,00 & 4505,00 \\
7 & L211 & 83,33 & 32 & 49 & 2666,67 & 4083,33 \\
8 & N101 & 83,25 & 44 & 64 & 3663,00 & 5328,00 \\
9 & N201 & 79,50 & 52 & 58 & 4134,00 & 4611,00 \\
10 & R202 & 74,80 & 64 & 71 & 4787,20 & 5310,80 \\
11 & N202 & 73,60 & 66 & 69 & 4857,60 & 5078,40 \\
12 & L102 & 73,00 & 60 & 48 & 4380,00 & 3504,00 \\
13 & R102 & 72,40 & 76 & 61 & 5502,40 & 4416,40 \\
14 & L201 & 70,75 & 60 & 48 & 4245,00 & 3396,00 \\
15 & L112 & 69,00 & 64 & 44 & 4416,00 & 3036,00 \\
16 & L202 & 69,00 & 71 & 37 & 4899,00 & 2553,00 \\
17 & K102 & 67,14 & 130 & 62 & 8728,57 & 4162,86 \\
18 & L212 & 67,00 & 76 & 32 & 5092,00 & 2144,00 \\
19 & K202 & 60,57 & 148 & 41 & 8964,57 & 2483,43 \\
20 & N102 & 59,14 & 163 & 30 & 9640,29 & 1774,29 \\
\hline & Total Jarak Tempuh Layout Arus “L” & & $89.639,96$ & $88.815,8381$ \\
\hline
\end{tabular}

\section{SIMPULAN}

Setelah dilakukan perhitungan jarak untuk 3 jenis tata letak yang telah dirancang, maka didapatkan hasil perbandingan jarak tempuh pada seluruh tata letak dengan jarak tempuh terkecil terdapat pada Tata Letak Arus Lurus Sederhana.

Berdasarkan perbandingan tersebut didapatkan jarak total terkecil terjadi pada tata letak arus lurus sederhana dan terjadi penurunan $11,11 \%$ dari tata letak awal. Sehingga dapat disimpulkan bahwa tata letak yang akan dipilih adalah tata letak alternatif 1 dengan arus lurus sederhana.

\section{DAFTAR PUSTAKA}

Apple, James M. 1990. Tata Letak Pabrik dan Pemindahan Bahan. ITB Bandung,

Francis, R. J., and White, J. A. Facility Layout and Location: An Analytical
Approach. New Jersey: Engle Wood Cliffs, 1992.

Hidayat. 2012, Perancangan Tata Letak Gudang dengan Metoda Class-Based Storage. Jurnal Alazhar Indonesia Seri Sains Dan Teknologi, Vol. 1. No. 3.

Purnomo, Hari. 2004, Perencanaan dan Perancangan Fasilitas. Edisi Pertama. Yogyakarta: Graha Ilmu

Tompkins, White, Bozer \& Tanchoco. 2010. Facilities Planning: Fourth Edition. New York: Wiley.

Reinny P, Indrawati. Perancangan Tata Letak Gudang Dengan Metode Dedicated Storage Location Policy (Studi Kasus : PT. X), Teknik Industri Universitas Andalas (2010)

Sukania, I Wayan, Silvi Ariyanti, Nathaniel. Usulan Perbaikan Tata Letak Pabrik dan Material Handling Pada PT. XYZ. Jurnal Ilmiah Teknik Industri, Teknik Industri Universitas Tarumanagara (2016). 
Sule, D.R. Manufacturing Facilities

Location, Planning, and Design: Third

Edition. New York: CRC Press, 2009.

Warman, John. Manajemen Pergudangan.

Jakarta: Pustaka Sinar Harapan, 2012. 
